\title{
Meta-Analisis Pengaruh Model Example Non Example dalam Pembelajaran IPA di Sekolah Dasar
}

\author{
LUIS KOMALA ${ }^{1)}$, LALU HAMDIAN AFFANDI ${ }^{2)}$, BAIQ NISWATUL KHAIR ${ }^{3)}$ \\ ${ }^{1}$ Alumni S1 PGSD FKIP Universitas Mataram, ${ }^{2,3}$ Dosen PGSD FKIP Universitas Mataram \\ e-mail: komalaluis98@gmail.com
}

\begin{abstract}
ABSTRAK
Tujuan penelitian ini untuk menganalisis besar efektivitas pengaruh model example non example terhadap pembelajaran IPA. Metode penelitian yang digunakan adalah meta-analisis terhadap penelitian-penelitian sebelumnya yang menerapkan pembelajaran model example non example dalam pembelajaran IPA. Penelitian diawali dengan merumuskan masalah penelitian, menelusuri hasil penelitian yang relevan untuk dianalisis. Data dikumpuklkan dengan menelusuri jurnal elektronik melalui Google Cendekia. Dari penelusuran diperoleh 8 artikel ilmiah yang telah dipublikasikan, instrument berupa pemberian kode (coding) dengan berpacu pada kriteria yang sudah ditentukan. Data dianalisis dengan menggunakan effect size. Temuan penelitian mengungkapkan bahwa secara keseluruhan penelitian-penelitian yang dilakukan berpengaruh dan efektif terhadap pembelajaran IPA di sekolah dasar dengan effect size 1,323132 atau dalam kategori efek tinggi. Model example non example pun memberikan pengaruh dan efektif dilihat dari tingkatan kelas yakni pada kelas 4,5, dan 6, dan penerapan pembelajaran untuk meningkatkan hasil belajar, kemampuan berpikir kritis, dan kemampuan menjelaskan. Simpulan penelitian ini adalah bahwa model example non example lebih efektif pada pembelajaran IPA dibandingkan dengan metode pembelajaran lain dari studi ini.
\end{abstract}

Kata kunci: Model Example Non Example, Pembelajaran IPA

\section{ABSTRACT}

The purpose of this study was to analyze the effectivenees of the effect od the example non example model on science learning. The research method used is a meta-analysis of previous studies that apply the example non example learning model in science learning. The research begins with formulating a research problem, tracing the relevant research results for analysisi. Data is collected by browsing electronic journals via google scholar. Form the search, it was obtained 8 scientific articles that have been published, the instrument was in the form of coding based on predetermined criteria. Data were analyzed using the effect size. The research findings reveal that overall the studies conductes are effective and effective on science learning in elementary scools with an effect size of 1,323132 or in the high efficiency category. The example non example model also has an effect and is effective at the grade level, namely in grade 4,5 and 6 and the application of learnin to improve learning outcomes, critical thinking skills, and the ability to explain. The conclusion of this study is that the example non example model is more effective in science learning compared to other learning models from this study.

Keywords: the example non example model, natural science learning

\section{PENDAHULUAN}

Pendidikan merupakan faktor terpenting dalam membentuk sebuah karakter dimulai dari nilai, sikap dan perilaku seseorang, khususnya sekolah dasar bertujuan untuk membentuk karakter yang baik. Permendikbud No 22 Tahun 2016 tentang Standar Proses Pendidikan Dasar dan Menengah menyatakan bahwa proses pembelajaran pada satuan pendidikan diselenggarakan secara interaktif, inspiratif, menyenangkan, menantang, memotivasi peserta didik untuk berpartisipasi aktif, serta memberikan ruang 
yang cukup bagi prakarsa, kreativitas dan kemandirian sesuai dengan bakat, minat, dan perkembangan fisik secara psikologis peserta didik (Tinenti, 2018:1).

Sekolah atau lebih khususnya kepada tenaga pendidik, dituntut agar mampu mengelola kelas dengan baik, membuat siswa untuk lebih aktif, kreatif, inovatif, interaktif, dan komunikatif dalam proses pembelajaran atau dengan kata lain student center, sudah tidak lagi techer center, guru akan berperan sebagai motivator, pengarah, fasilitator, dan lainnya. Selain itu, guru adalah orang yang berperan dalam menciptakan sumber daya manusia yang berkualitas yang dapat bersaing di era saat ini. Kemampuan guru dalam melaksanakan proses belajar mengajar sangat berpengaruh terhadap tingkat pemahaman siswa.

Salah satu pelajaran yang memiliki peran penting dalam bidang ilmu pengetahuan adalah Ilmu Pengetahuan Alam (IPA). Pembelajaran IPA pada hakikatnya meliputi empat unsur utama. Menurut Depdiknas (2006) yaitu meliputi unsure sikap, proses, produk dan aplikasi (dalam Ardika, dkk, 2018:102). Keempat unsur ini merupakan ciri IPA yang utuh dan tidak dapat dipisahkan satu sama lain. Dalam belajar IPA, siswa mencari tahu tentang alam secara sistematis yang berupa fakta-fakta, konsep-konsep, atau prinsip-prinsip dan siswa juga melakukan suatu proses penemuan. Suwono (2012) menyatakan bahwa pembelajaran IPA menekankan pada pemberian pengalaman belajar secara bermakna melalui penggunaan dan pengembangan keterampilan proses dan sikap ilmiah (dalam Khair, dkk 2018:98). Dengan demikian siswa mengalami proses pembelajaran secara utuh, memahami fenomena alam melalui kegiatan pemecahan masalah dan metode ilmiah.

Kompetensi-kompetensi yang harus dicapai siswa di atas menjadi kebutuhan peserta didik terutama pembelajara IPA sehingga tujuan pembelaran dapat tercapai dan tergambar pada hasil belajar siswa. Oleh sebab itu perlu adanya inovasi dalam pembelajarn IPA, agar proses pembelajaran dapat berlangsung optimal dan tujuan pembelajran dapat tercapai. Pembelajaran yang inovatif dan efektif diperlukan agar peserta didik dapat berperan aktif dalam pembelajaran serta guru pun harus memilih model atau metode yang sesuai dengan materi karena IPA secara keselruhan merupakan belajar memecahkan masalah.

Salah satu model yang banyak digunakan untuk menunjang pembelajaran yang memberdayakan siswa dan berpusat pada keaktifan siswa adalah example non example (contoh dan bukan contoh). Model example non example merupakan sebuah langkah mensiasati agar siswa dapat mendefinisikan sebuah konsep, strategi yang bisa digunakan dan bertujuan untuk mempersiapkan siswa secara cepat dengan menggunakan dua hal yang terdiri dari example (contoh akan suatu materi yang sedang dibahas) dan non example (contoh dari suatu materi yang sedang tidak dibahas), dan siswa mengklasifikasikan keduanya seesuai konsep yang ada (Kurniasih dan Sani, 2015:32). Melalui model example non example ini siswa menganalisis gambargambar dan siswa memberikan deskripsi sesuai dengan apa yang mereka pahami. Model example non example bertujuan mendorong siswa untuk belajar berpikir kritis dengan memecahkan permasalahanpermasalahan yang termuat dalam contoh-contoh gambar yang disajikan, dengan melakukan analisis, siswa dilatih untuk berpikir kritis.

Suryani (2017:117) menyatakan bahwa terdapat pengaruh penerapan model pembelajaran example non example terhadap keterampilan berpikir kritis siswa, karena model ini bertujuan untuk mendorong siswa untuk belajar berpikir kritis untuk memecahkan permasalahan-permasalahan yang termuat dalam contoh gambar yang disajikan. Saputra (2016:8) juga menyatakan bahwa ada pengaruh penggunaan model example non example terhadap kemampuan mengidentifikasi sifat benda. Hal ini dapat terjadi karena karena model pembelajara example non example dapat membantu dan memotivasi siswa sehingga tujuan pembelajaran tercapai secara maksimal dan juga model ini membuat siswa aktif dan kreatif di dalam pembelajaran.

Beberapa studi eksperimen terhadap pembelajaran example non example telah dilakukan yaitu penelitian oleh Suryani pada tahun 2017; Rustono dan Nugraha pada tahun 2018; Saputra pada tahun 2016; Aisah dan Asmahasanah pada tahun 2017; Lisnaini pada tahun 2019; Aji dan Sari pada tahun 2019; Fadjrin pada tahun 2020 dan masih banyak lagi peneliti yang meneliti tentang model pembelajaran example non example. Berdasarkan banyaknya penelitian terdahulu yang sejenis maka perlu dilakukan pengorganisasian data, menggali informasi sebanyak mungkin, dan juga perlu dilakukan analisis kembali secara keseluruhan untuk melihat seberapa besar pengaruh model example non example terhadap pembelajaran IPA siswa pada sekolah dasar menggunakan teknik meta-analisis.

\section{Rumusan Masalah}

Berdasarkan latar belakang di atas maka rumusan masalah penelitian yaitu "Meta-analisis Pengaruh Model Example Non Example pada Pembelajaran IPA di Sekolah Dasar". 


\section{Tujuan dan Manfaan Penelitian}

Tujuan dari penelitian ini yaitu untuk mendeskripsikan hasil meta-analisis mengenai Pengaruh Model Example Non Example pada Pembelajaran IPA di Sekolah Dasar. Sedangkan manfaat dalam penelitian ini yaitu sebagai dasar pembanding teori dalam memilih model example non example pada Pembelajaran IPA di Sekolah Dasar.

\section{METODE PENELITIAN}

Penelitian ini merupakan penelitian kuantitatif. Bentuk penelitian kuantitatif yang digunakan dalam penelitian ini adalah meta analisis, yaitu penelitian untuk melihat besarnya pengaruh terhadap suatu perlakuan. Analisis meta (meta analysis), merupakan penelitian menggunakan studi-studi yang telah ada dan telah digunakan oleh peneliti lain yang dilakukan secara sistematis dan kuantitatif untuk memperoleh kesimpulan yang akurat (Retnawati, 2018:1). Dalam Penelitian meta-analisis digunakan untuk menganalisis penelitian-penelitian empiris yang telah dilakukan oleh peneliti sebelumnya, hasil penelitian kuantitatif, hasil penelitian dalam bentuk yang dapat dibandingkan.

Pengumpulann data dilakukan dengan menelusuri google cendekia atau google scholar. Instrumen untuk pengumpulan data adalah dengan menggunakan lembar pengkodean (coding). Variabel-variabel yang akan diberikan kode yaitu: 1) judul penelitian, 2) tahun penelitian, 3) nama peneliti, dan Hasil pretest dan posttest pada tiap penelitian dalam bentuk skor. Sampel yang digunakan dalam penelitian ini adalah 15 artikel publikasi ilmiah. Teknik analisis data menggunakan analisis gain score, untuk mengetahui besar efektivitas dari metode example non example dalam pembelajaran IPA di sekolah

\section{HASIL DAN PEMBAHASAN}

Hasil penelitian terdahulu yang diikutkan dalam penelitian meta-analisis ini adalah:

1. Pengaruh Penggunaan Model Pembelajaran Examples Non Examples terhadap Hasil Belajar IPA Siswa Kelas V di SDN Sidodadi Kecamatan Batang Kuis Kabupaten Deli Serdang oleh Wenny Elmarisa Nur Harahap.

2. Pengaruh Model Cooperative Learning Tipe Example Non Example terhadap Hasil Belajar Siswa pada Mata Pelajaran IPA oleh Siti Aisah dan Salati Asmahasanah.

3. Pengaruh Model Pembelajaran Example Non Example untuk Meningkatkan Hasil Belajar Tematik bagi Siswa Kelas VI oleh Lisnani.

4. Pengaruh Model Example Non Example Dengan Media 3 Dimensi terhadap Kemampuan Menjelaskan Dampak Pengambilan Bahan Alam terhadap Pelestarian Lingkungan Siswa Kelas 4 SDN Tamanan Kota Kediri tahun ajaran 2014/2015 oleh Novianti Ajeng Pramita.

5. Pengaruh Penggunaan Model Example Non-Example terhadap Peningkatan Kemampuan Berpikir Kritis Peserta Didik Sekolah Dasar pada Mata Pelajaran Ilmu Pengetahuan Alam oleh Nadia Diani Yuliani.

6. Perbedaan pengaruh Model Pembelajaran Picture And Picture Dan Example Non Example terhadap Kecakapan Berpikir Kritis Muatan IPA kelas IV sekolah dasar oleh Andi Yuliyono dan Elvira Hosein Radia.

7. Pengaruh Model Pembelajaran Example Non Example terhadap Hasil Belajar Ilmu Pengetahuan Alam Siswa Kelas IV MIN 5 Kota Medan Tahun Ajaran 2019/2020 oleh Sa'adah Harahap.

8. Perbandingan Model Pembelajaran Picture And Picture Dengan Model Pembelajaran Example Non Example terhadap Hasil Belajar Ilmu Pengetahuan alam (IPA) di kelas V MI Al-Islam Kota Bengkulu oleh Ummi Rolita Anggraini.

\section{Effect Size Model Example Non Example dalam Pembelajaran IPA}

a. Data hasil effect size secara keselururhan

Data besar pengaruh (effect size) artikel publikasi ilmiah pembelajaran example non example berdasarkan kategori terdiri dari empat kriteria yaitu efek lemah, efek sederhana, efek sedang, dan efek tinggi dapat dilihat pada tabel 1 berikut:. 
Tabel 1. Hasil Analisis Effect Size Secara Keselururhan

\begin{tabular}{ccccccl}
\hline \multirow{2}{*}{ No } & \multicolumn{2}{c}{ Eksperimen } & \multicolumn{2}{c}{ Kontrol } & \multirow{2}{*}{ Efffect size } & \multirow{2}{*}{ Kategori } \\
\cline { 2 - 5 } & Pretest & Posttes & Pretes & Posttes & & \\
\hline 1 & 54.17 & 89 & 50.36 & 72.32 & 2.874626 & Efek tinggi \\
\hline 2 & 50 & 79.5 & 40 & 67.5 & 1.552622 & Efek tinggi \\
\hline 3 & 46.19 & 88.16 & 16.88 & 56.19 & 1.766292 & Efek tinggi \\
\hline 4 & 63.17 & 81.85 & - & - & 2.912833 & Efek tinggi \\
\hline 5 & 50.6 & 82.6 & 52.6 & 72.9 & 1.376139 & Efek tinggi \\
\hline 6 & 70.43 & 80.43 & 68.94 & 73.74 & 0.849496 & Efek sedang \\
\hline 7 & 54.75 & 86.25 & 60 & 83 & 0.327265 & Efek sederhana \\
\hline 8 & 51.1 & 80.1 & 44.1 & 68.9 & 0.930909 & Efek sedang
\end{tabular}

Rerata Effect Size

1.323132 (Efek tinggi)

SD

0.929939

Perhitungan analisi effect size yang dlakukan menggunakan bantuan aplikasi Microsoft office excel 2007. Hasil data analisis pada tabel 1 menunjukkan bahwa dari 8 artikel publikasi ilmiah yang di analisis memberikan harga effect size yang berbeda-beda, yang mana satu artikel dengan efek sederhana, dua artikel dengan efek sedang dan lima artikel dengan efek tinggi. Dari perhitungan diperoleh effect size total sebesar 1,323132 dalam kategori efek tinggi dan simpangan baku sebesar 0,929939.

b. Data Hasil Effect Size Berdasarkan Tingkatan Kelas yang digunakan

Tabel 2. Hasil effect size berdasarkan tingkatan kelas

\begin{tabular}{|c|c|c|c|l|}
\hline No & Kelas & N artikel & Effect size & \multicolumn{1}{|c|}{ Kategori } \\
\hline 1 & 4 & 3 & 0.9492347 & Efek sedang \\
\hline 2 & 5 & 4 & 0.9737257 & Efek sedang \\
\hline 3 & 6 & 1 & 1.766292 & Efek tinggi \\
\hline
\end{tabular}

Tabel 2 menggambarkan bahwa penggunaan metode example non example dalam pembelajaran IPA paling banyak digunakan pada kelas lima dengan empat artikel, sedangkan penggunaan yang paling sedikit pada kelas enam dengan satu artikel. Namun jika dilihat dari effect size bahwa penggunaan model example non example dalam pembelajaran IPA dari artikel publikasi ilmiah bahwa pada kelas empat dengan harga effect size 0.9492347 dengan kategori sedang, pada kelas lima dengan harga effect size 0.9737257 dengan kategori sedang, dan pada kelas enam dengan harga effect size 1.766292 dengan kategori tinggi. Tabel tersebut mengungkapkan bahwa pengaruh paling tinggi terdapat di kelas enam, sehingga kelas enam paling efektif menggunakan model example non example dibandingkan dengan kelas lainnya.

\section{c. Data Hasil Effect Size Berdasarkan Variabel Terikat Penelitian}

Tabel 3. Hasil Effect Size Berdasarkan Variabel Terikat Penelitian

\begin{tabular}{|l|l|l|l|l|}
\hline No & Variabel Terikat & N Artikel & Effect Size & Kategori \\
\hline 1 & Hasil belajar & 5 & 1.0966583 & Efek tinggi \\
\hline 2 & Kemampuan Menjelaskan & 1 & 2.912833 & Efek tinggi \\
\hline 3 & Berpikir kritis & 2 & 7.0436825 & Efek tinggi \\
\hline
\end{tabular}

Tabel 3 menampilkan penelitian tentang variabel terikat penelitian mengenai penerapan pengajaran berupa output yang diharapkan yaitu hasil belajar dengan jumlah terbanyak dengan lima artikel publikasi ilmiah dengan effect size 1.0966583, dilanjut dengan berpikir kritis pada tingkat selanjutnya dengan dua artikel publikasi ilmiah dengan effect size 7.0436825, sedangkan kemampuan menjelaskan satu artikel publikasi ilmiah dengan effect size 2.912833. Dari semua variabel terikat penelitian yang dianalisi menghasilkan besar pengaruh dengan efek yang tinggi, yang mana efek tertinggi terdapat pada kemampuan berpikir kritis. Sehingga dapat dikatakan bahwa model example non example sangat efektif digunakan untuk meningkatkan berbagai macam kemampuan yang ada pada diri siswa. 


\section{Karakteristik Model Example Non Example yang Efektif}

Metode example non example dari 8 jurnal yang dianalisis dikatakan efektif karena dalam penerapannya masing-masing peneliti melaksanankan setiap langkah-langkah yang ada pada metode tersebut dengan baik yakni 1) Guru mempersiapkan gambar-gambar sesuai dengan tujuan; 2) Guru menempelkan gambar di papan atau ditayangkan lewat LCD; 3) Guru membentuk kelompok-kelompok yang masingmasing terdiri dari 2-3 siswa; 4) Guru memberi petunjuk dan memberi kesempatan kepada setiap kelompok untuk memperhatikan dan/atau menganalisis gambar; 5) Mencatat hasil diskusi dan analisis gambar pada kertas; 6) Memberi kesempatan bagi tiap kelompok untuk membacakan hasil diskusinya; 7) Berdasarkan komentar atau hasil diskusi siswa, guru menjelaskan materi sesuai tujuan yang ingin dicapai; dan 8) Penutup.

\section{Pembahasan}

Berdasarkan langkkah-langkah penelitian yang sudah dilakukan, karakteristik atau ciri khas penggunaan metode example non example yaitu pada tahap pengamatan atau analisis gambar yang contoh "example" dan yang bukan contoh "non example" yang berkaitan dengan materi. Tahap ini guru menampilkan suatu gambar yang sesuai dengan materi pembelajaran dan gambar tersebut diamati dan dianalisis oleh siswa. Dengan menunjukkan gambar-gambar tersebut siswa diajarkan untuk memecahkan suatu masalah, memperluas pemahaman sebuah konsep dan melalui pengamatan gambar dapat menarik perhatian siswa. Penggunaan media gambar ini efektif di gunakan dalam proses pembelajaran karena memiliki kelebihan-kelebihan, sebagaimana yang dikemukakan oleh Herawati dan Bachri (2018:106) bahwa media gambar bersifat konkret karena siswa melihat secara nyata dalam bentuk tiruan, sehingga siswa tidak salah membayangkan suatu benda, media gambar dapat mengatasi ruang dan waktu karena tidak semua benda, objek atau pristiwa dapat dibawa ke dalam kelas. Selain itu, dari penelitian yang dilakukan oleh Lestari (2017) penggunaan media gambar dapat meningkatkan aktivitas belajar siswa, karena dalam proses pembelajaran siswa lebih tertarik dengan pembelajaran yang disampaikan guru, lebih aktif dan tidak pasif lagi. Siswa lebih banyak melakukan kegiatan belajar, karena siswa tidak hanya mendengarkan penjelasn guru tetapi juga melakukan aktivitas lain seperti mengamati gambar. Gambar yang digunakan dalam metode example non example ini dapat ditampilkan melalui LCD, proyektor, atau yang paling sederhana yaitu poster atau poto (Huda, 2017:234). Gambar ini haruslah jelas terlihat meski dari jarak jauh, sehingga siswa yang berada pada di bangku belakang dapat juga melihatnya dengan jelas.

Selain tahap pengamatan atau analisis gambar, pada tahap diskusi kelompok dalam metode ini juga melatih siswa untuk mengkomunikasikan pendapatnya. hal inilah yang kemudian akan mengurangi kemungkinan adanya anggota yang tidak aktif. Dengan adanya kegiatan diskusi dalam metode example non example ini, dapat memberikan kesempatan kepada siswa membahas suatu permasalahan atau topik dengan cara setiap siswa mengajukan pendapat, saling tukar pemikiran untuk memperoleh kesimpulan bersama dari diskusi yang telah dilakukan. Pandangan tersebut sebagaimana ditekankan oleh Buehl (1996) bahwa keuntungan dari metode ini ialah memberi kesempatan kepada siswa untuk mengemukakan pendapatnya, sehingga siswa dapat menunjukkan partisipasi mereka kepada orang lain, siswa diajarkan untuk kritis dalam menganalisis gambar (dalam Budiyanto, 2016:64). Selain itu, Khasanah (2020:79) mengemukakan bahwa kegiatan diskusi kelompok memungkinkan siswa untuk menguasai suatu konsep atau memecahkan suatu masalah melalui satu proses yang memberikan kesempatan untuk berpikir, berinteraksi sosial, serta berlatih bersikap positif. Dengan demikian diskusi kelompok dapat meningkatkan kreativitas siswa serta membina kemampuan berkomunikasi.

Pelaksanaannya di lapangan, guru hendaknya hanya menjadi fasilitator dan juga guru hanya memantau aktivitas siswa dengan cara berkeliling dan memberikan arahan jika siswa mengalami kendala dalam proses diskusi. Sebagaimana yang dikemukakan oleh Chomaidi dan Salamah (2018:207) bahwa dalam suatu diskusi kedudukan guru hendaknya sebagai fasilitator, sebagai pemimpin yang yang selalu menghidupkan jalannya diskusi, mengatur lalu lintas pembicaraan, dan sebagai penunjuk jalan.

Berdasarkan hasil-hasil penelitian yang telah dilakukan dapat dilihat bahwa setiap penelitian memperoleh nilai effect size yang berbeda-beda Hal ini dipengaruhi oleh berbagai faktor baik dari faktor internal dan eksternal. Faktor internal seperti biologis (kesehatan dan kondisi tubuh) dan psikologis (minat, bakat, serta intelegensi). Faktor eksternal seperti lingkungan keluarga (orang tua, suasana rumah, kondisi ekonomi keluarga), lingkungan sekolah (kurikulum, guru, proses pembelajaran, hubungan sosial antara guru dengan siswa, siswa dengan siswa, kondisi sekolah, pelaksanaan disiplin sekolah), lingkungan masyarakat (hubungan dengan tetangga), dan waktu. 


\section{PENUTUP}

\section{Simpulan}

Berdasarkan temuan dan analisis hasil penelitian yang telah dilakukan, maka dapat disimpulkan sebagai berikut: 1) Berdasarkan meta-analisis terhadap 8 artikel publikasi ilmiah yang dilakukan dapat disimpulkan bahwa besar pengaruh metode example non example dalam pembelajaran IPA di sekolah dasar dengan perhitungan effect size total sebesar 1,323132 dalam kategori efek tinggi dan simpangan baku sebesar 0,929939, dengan masing-masing artikel dengan harga effect size yang berbeda-beda, yang mana satu artikel dengan efek sederhana, dua artikel dengan efek sedang dan lima artikel dengan efek tinggi. 2) Karakteristik atau ciri khas metode example non example yang memberikan efektivitas dalam pembelajaran IPA yaitu pada tahap pengamatan atau analisis gambar yang contoh "example" dan yang bukan contoh "non example", dan juga pada tahap diskusi dalam metode ini akan melatih siswa untuk mengkomunikasikan pendapatnya. 3) Masing-masing penelitian memperoleh nilai effect size yang berbeda-beda dipengaruhi oleh dua faktor yakni faktor internal dan faktor eksternal.

\section{Saran}

Setelah peneliti melakukan proses penelitian meta-analisi, maka penulis mengajukan beberapa saran sebagai perbaikan di masa yang akan datang: 1) Guru dapat menggunakan metode example non example dalam proses pembelajara IPA di sekolah perlu memilah dan menyesuaikan konsep materi yang dianggap sesuai dengan metode pembelajaran dan mampu mengelola kelas baik dalam mengarahkan peserta didik agar tercapainya tujuan pembelajaran. 2) Bagi peneliti, seorang peneliti agar lebih detail lagi dalam mencantumkan kelengkapan data penelitian untuk artikel ilmiah, baik metode, data sampel maupun data hasil penelitian. 3) Bagi penelitian selanjutnya agar lebih banyak menggunakan artikel yang digunakan dalam penelitian meta-analisis supaya data yang diperoleh lebih luas dan bisa dilihat lebih mendalam hasil penelitiannya.

\section{DAFTAR PUSTAKA}

Ardika, Wayan, dkk. (2018). Inovasi dalam Pembelajaran: Kumpulan Naskah Finalis Inobel dan Juara ONIP Matematika Guru Jembrana 2017. Bali: CV Grapena Karya.

Budiyanto, Agus K. (2016). Sintaks 45 Metode Pembelajaran dalam Student Centered Learning (SCL). Malang: Universitas Muhamadiyah Malang (UMM) Press.

Chomaidi dan Salamah. (2018). Pendidikan dan Pengajaran: Strategi Pembelajaran Sekolah. Jakarta: PT Grasindo.

Huda, Miftahul. (2017). Model-model Pengajaran dan Pembelajaran. Yogyakarta: Pustaka Pelajar.

Khair, B. N., Susilo, H., \& Suarsini, E (2018). Pengembangan Bahan Ajar IPA Berbasis Inkuiri Untuk Siswa Kelas V SD. ELSE (Elementary School Education Journal): Jurnal Pendidikan dan Pembelajaran Sekolah Dasar, 2(1), 97-108.

Khasanah, Uswatun. (2020). Pengantar Microteaching.Yogyakarta: Deepublish Publisher.

Kurniasih, Imas \& Sani, Berlin. (2015). Ragam Pengembangan dan Model Pembelajaran. Jogjakarta: Kata Pena

Lestari, D. A (2017). Peningkatan Aktivitas dan Hasil Belajar IPA dengan Model Discovery Berbantuan Media Gambar di Kelas V SD Negeri Pakis 1 Magelang Semester 1 Tahun Ajaran 2016/2017. Pusat Dokumentasi dan Informasi Ilmiah - Lembaga Ilmu Pengetahuan Indonesia.

Retnawati, dkk. (2018). Pengantar Analisi Meta. Yogyakarta: Parama Publishing.

Saputra, A. K. Pengaruh Penggunaan Model Example Non Example dengan Media Benda Konkrit terhadap Kemampuan Mengidentifikasi Sifat Benda pada Sisiwa Kelas III SDN Mrican 1 Kota Kediri Tahun $2015 / 2016$.

Suryani, S. (2017). Pengaruh Media Kartu Bergambar Melalui Model Pembelajaran Example Non Example terhadap Keterampilan Berpikir Kritis dan Afektif Peserta Didik pada Materi Pokok Ekosistem (Doctoral dissertation, IAIN Raden Intan Lampung).

Tineti, Yanti R. (2018). Model Pembelajaran Berbasis Proyek (PBP) dan Penerapannya dalam Proses Pembelajaran di Kelas. Yogyakarta: CV Budi Utama. 